\title{
NOTES FROM THE LIBRARY
}

\section{OHN WOOLMAN ON WAR}

Among the Woolman manuscripts in the Rutgers University Library are three short pieces which are uniform with the second and perhaps most important manuscript of the Fournal of Fobn Woolman. Like it they are carefully written on note paper, six by eight inches in size, with the sheets sewn together. The first, which transcribes a passage from the fournal with many slight variations in text, describes a religious journey to the Western Shore of Maryland in April, I767. It is interesting chiefly because it constitutes a third manuscript of this passage and re-emphasizes Woolman's care in preparing the record of his religious life and labors. ${ }^{1}$

The second is not by Woolman, although it is in his hand and is likewise uniform with the second manuscript of the Fournal. It describes the efforts of John Churchman to dissuade the Pennsylvania Assembly from voting for a military program in April, I748, when the Governor called them together and "laid before them the defenseless State of Pennsylvania, in order to prevail with the house to give a Sum of money to Station a Ship of force at our capes as also to Encourage the Building a Battery below the City." Woolman so much sympathized with Churchman's effort that he asked him for his record of the event, copied it in full, and then transcribed it in the third and last manuscript of his own Fournal, with the words, "If this Journal be printed, let all the Quoton from J. Churchman's notes be left out." His editors followed his directions. ${ }^{2}$

The third is a short account of a dream, apparently by Woolman but not contained in any of the manuscript or printed versions of the Fournal. It would serve as an allegorical interpretation of Churchman's experience and is a dramatic record of the Quaker testimony against war. As other dreams were omitted from the early printed texts of the fournal, it may have been originally intended as a part of that work. The text is here reproduced in full:

Da. 26 Mo. 71764 at night I dreamed I was abroad on a Religious Visit, beyound the Sea, and had been out upward of two months, and that while I was out on the Visit, the people of the Country where I was, \& those of a Neighbouring Kingdom, having concerns together in affairs abroad had difference, which arose so high that they began to fight, and both parties were preparing for a General war. I thought there was no Sea between them, but only bounded by a line, and that the man who was Chief amongst the other people, lived within a Days Journey of where I was. I being troubled at these things felt a desire in my mind to go \& Speak with this Chief man, and try to prevail on him to Stop Fighting,

${ }^{1}$ Ms. \#2: (Friends Historical Library of Swarthmore College) pp. 3I I-3I9.

2 Ms. \#3: (Historical Society of Pennsylvania) pp. 70-76. See also, A. M. Gummere's T'be Fournal and Essays of Fobn Woolman. N. Y. I922. p. 206 n. The passage was printed in John Churchman's Gospel Labours. Phila. I779. 
that they might enquire more fully into the grounds of their disagrem ${ }^{t}$ and endeavour to accomodate their difference without sheding more Blood. So I set of, having one man with me as a pilot, and after traveling some time in the woods, we came in sight of a few of those people at Labour, having Guns with them; I being foremost came near them before they saw us, and as soon as they discovered that we were from their Enemies Country, they took up their Guns, and were preparing to fire on us; where upon I hastily approached them, holding up both my Arms, to let them see that I had no warlike weapons, So I Shook hands with them, \& let them know the cause of our coming, at which they appeard well pleased. In the surprize at our meeting, my Pilot held forth a small Gun he had with him, which I knew not of before, but they so soon understood our Business that none fired; After which I saw my Pilot no more; But one of these people offering to Conduct me to their Chief Man, He and I set forward \& Traveled along a path through Woods, \& Swamps near South-East, and on our way, my new Pilot, who could talk broken English, spake to me with an agreable countenance, \& desired that when I came before their Chief, I would speak my mind freely, 8 signified their Salutation at meeting was to Speak to each other but not to Shake hands. At length we came to the House of this Chief man, whom I thought had the Command of the Soldiers, and was at the head of the Affairs of their Country, but was not called a King. His House Stood by it self, \& a good Garden with green herbs before the Door. In which Garden I stood, while my Pilot went to tell this Chief man that I wanted to speak with him. As I stood alone in the Garden, my mind was Exercised on the affair I came upon, and presently my Pilot returned, and passing by me said he had forgot to tell me that I had an invitation to Diner. Soon after him came the Chief man, who having been told the cause of my coming looked on me with a Friendly Countenance, and as I was about to enter on the business I awoke

John Woolman

Robert E. Spiller

\section{Swartbmore College}

\section{A WOOLMAN DOCUMENT}

Among some papers by and pertaining to John Woolman, the eighteenth-century Quaker leader and diarist, the Rutgers Library owns a deed recording Woolman's purchase of land from Jacob Powell for the sum of $£_{12}$ on August 9, I762. This transfer of land is reaffirmed by Jacob's widow, Mary Powell, on April 30,1764 , on the same piece of parchment.

The location of this property is uncertain. Mr. Nathaniel R. Ewan, past President of the Burlington County Historical Society, writes, "Some authorities claim that the Cripps original plantation was between Mt. Holly and Lumberton, but do not offer any documentary proof, and I doubt very much if anyone can definitely place his settlement, except within a rather extended area around the present site of Mt. Holly, where the old name of Cripps Mount was the traditional designation." Mr. George De Cou adds, "Nathaniel Cripps had a daughter named Virgin who married one John Powell, and they had grandchildren named Jacob, Christopher, John, and Joseph Powell. I do not know, however, where these men lived. The following record of 
survey, from Basse's Book of Surveys, p. I47, is suggestive: 'Feb. I708-o9, for Nathaniel Cripps and Thomas Bryant of 500 acres at an Indian town called Coexon upon a small branch of Ancocas Creek.' The Indian village of Coexon, spelled in various ways, was located about a mile or mile and a half west of Vincentown, so this farm must have been in that neighborhood. In $\mathrm{Na}$ thaniel Cripps' will, dated October 9, 1746 , he mentions 'The brick house near Bridgetown [Mt. Holly] and sixty acres of land."

Vincentown is south of Mt. Holly, and therefore located in the opposite direction with respect to the town from John Woolman's ancestral home, so that there is no possibility that he bought this tract to extend family holdings. The farm which he bought in 1747 is not in that immediate neighborhood either. The neighborhood one and a half miles west of Vincentown, toward the Lumberton road, is flat territory, with relatively rich soil for this region, and there is considerable acreage through which a tiny stream flows. It is now in fields, and an orchard is near, but the presence of groves of trees would suggest that it might have been wooded when Woolman bought it.

The chief interest of this deed and the others in the Rutgers Library collection, which contain Woolman's signature in capacities other than those of seller or purchaser of land, is the evidence which they give of the great amount of legal work done by him in drawing up and signing wills, deeds, and conveyances, rather than for any important biographical facts. Mrs. Gummere points out that, whether he wished it or not, the sidelines which grew out of his tailoring business became profitable, even though he was scrupulous about taking money for legal chores. (Gummere, A. M.: T'be Fournal and Essays of Fobn Woolman. New York: I922, p. 47.) He must have been something of a real estate broker, for Mrs. Gummere says, "Deeds exist in which he bought and sold lands within forty-eight hours, evidently to settle estates." (Ibid., p. 50.) This was not the case with the Powell land transfer, however, for Woolman's title to it is reaffirmed by the widow. It is not a large plot of land compared to the acreage of some contemporary purchases, being only "one acre and 12 square rods of land"; but the sum $£_{12}$ is a good price per acre, and Woolman's reasons for its purchase are a matter of speculation. As there seem to be no other reasons, one might fairly suppose that he did it to help some needy friend, or otherwise for the benefit of someone other than himself.

Mary Ellis Darlington

\section{RUTGERS PUBLICATIONS}

Colonel James Neilson, A Business Man in the Early Macbine Age in New Fersey 1784-1862, by Robert T. Thompson.

Dr. Thompson's scholarly life of Colonel Neilson is an important study of a New Brunswick citizen whose career epitomized in many ways the transition period which ushered in the machine age in New Jersey.

Colonel Neilson (1784-I862) was the son of Colonel John Neilson of Revolutionary War fame, and the father of the late James Neilson 
whose death in 1937 robbed the university of one of its most loyal and devoted friends. Professor Thompson's study is based largely on the remarkable collection of Neilson manuscripts which Mr. Neilson presented to the Rutgers University Library before his death.

From this collection of source materials, the author has drawn a wellrounded and convincing portrait of a business man who seems to have been actively interested in almost all of the new industries which were springing up in the early part of the nineteenth century. Colonel Neilson conducted a successful shipping business between New Brunswick and New York; helped in the formation of the New Jersey turnpike and railroad companies; and was one of the key individuals in the development of the Delaware and Raritan Canal which ran between New Brunswick and Trenton. In addition, he took part in many speculative adventures in real estate in various parts of the country, and also helped to promote many manufacturing industries in New Brunswick. In this latter connection, the author's account of the change from water power to steam provides an interesting footnote to the history of the worldwide industrial revolution.

Perhaps the most interesting of Colonel Neilson's far-flung business ventures was his share in the development of the Delaware and Raritan Canal. The difficulties involved in organizing and promoting this enterprise would have discouraged any less resolute individual, but because of Colonel Neilson's unflagging faith in the future of the canal, the onerous task of construction was finally carried to a successful conclusion with the opening of the waterway in 1834 . It was largely through Neilson's unremitting efforts that the necessary capital was raised, and the charters secured from the reluctant legislatures of Pennsylvania and New Jersey.

Not the least rewarding activity in Neilson's many-sided career was his lifetime of experience as a gentleman farmer. The beautiful estate centering about "Wood Lawn" was the scene of continuing experiments in new methods of agriculture and it seems certain that Neilson took particular pleasure in this phase of his existence.

Toward Rutgers College, Colonel Neilson displayed a friendly and sympathetic interest at all times. He served as Trustee from 1833 until his death in 1862 , and during this period made numerous gifts to the struggling college in the form of lands and scholarship funds.

Dr. Thompson's announced purpose in writing this volume was to present Colonel Neilson as a typical "business man of the early machine age in New Jersey." In this he has succeeded admirably and the resultant study is a genuine contribution to American social history. Roger H. McDonough

Composing Sticks and Mortar Boards, by Earl Schenc Miers, with an Introduction by $\mathbf{P}$. J. Conkwright.

THIs curious volume is a skillful and light hearted book on universities and their presses. It answers the unasked question as to why so much university printing should be so commonplace. Like a good primer for those in charge of such matters, 
it also gives the practical advice we so seldom get from the pert askers of embarrassing questions. The volume is, as it should be, a model of good taste and restraint in design which is no more than we have come to expect from Richard Ellis who designed it.

To read Mr. Miers' account of printing a college catalogue, you would think such a routine job was an adventure in craftsmanship. He merely assumes that universities, the home and source of learning, ought to be the home and source of sound printing. This easy assumption carries with it another which is apparent on every page. It is that all university printers see beyond the dull editorial duties and compromises that have to be made daily with a narrow budget to the work itself in finished form which represents the dignity and prestige of the institution from which it comes. All you need is enthusiasm, patience, tact, taste, some knowledge; devotion to the institution, and a ten percent increase in the printing budget.

Donald F. Cameron

T'bat Rascal Freneau, A Study in Literary Failure by Lewis Leary.

Born in New York, Philip Freneau was brought to New Jersey when a small child, and there he lived most of the time for the remainder of his eighty years. It is appropriate that for years past the Rutgers Library should have been collecting books and manuscripts of this Jerseyman and that a distinguished biography, which draws such a substantial body of its material from that library, should be published by the Rutgers University Press.
In the course of hunting out the facts that have gone into this book, Dr. Lewis Leary has from time to time prepared short studies, two of which have been printed in the fournal. It is therefore with especial feeling of one who has watched a child grow from its early years that we greet this excellent volume, in which we have the additional pleasure of reading about familiar places as they were in the days of the eighteenth and early nineteenth centuries. For Freneau lived the greater part of his life at Mount Pleasant, near present-day Matawan.

During his life Freneau was a whole-hearted partisan. He gave his soul to the cause of freedom in the time of the Revolutionary War, and suffered in a British prisonship for his ardor. After that he became the editor of the Philadelphia Freemen's Fournal. In this capacity he continued to fight the British until the treaty of peace was finally concluded. Later he went to sea as a captain, and almost lost his life in a storm from the ravages of which only eight out of one hundred and fifty ships in the harbor of Kingston, Jamaica, survived. During the six years of his life at sea he constantly contributed poems to the newspapers of New York, Philadelphia, New Brunswick, and Charleston.

Dr. Leary is the first person who has ever brought together all the facts of Freneau's life so that one can see his career as a whole. In doing so, he has made an important contribution to our knowledge of the part played in our national life by the man who earned the title, "The Poet of the Revolution."

R. K. 